\title{
Anaphylaxis Induced by Conlinin, a 2S Storage Protein in Flaxseed
}

Basagaña $\mathrm{M}^{1}$, Prieto-García $\mathrm{A}^{2}$, Miquel $\mathrm{S}^{1}$, Micozzi $\mathrm{S}^{2}$, Bartolomé $\mathrm{B}^{3}$, Labrador-Horrillo $\mathrm{M}^{4}$, Roger $\mathrm{A}^{1}$

${ }^{1}$ Allergy Section, Hospital Universitari Germans Trias i Pujol, Universitat Autónoma de Barcelona, Badalona, Spain

${ }^{2}$ Allergy Department, Hospital General Universitario Gregorio Marañón, Instituto de Investigación Sanitaria Gregorio Marañón, Madrid, Spain

${ }^{3} R \& D$ Department, Roxall, Bilbao, Spain

${ }^{4}$ Allergy Section, Department of Internal Medicine, Hospital Universitari de la Vall d'Hebron, Universitat Autónoma de Barcelona, Barcelona, Spain

J Investig Allergol Clin Immunol 2018; Vol. 28(1): 56-58 doi: $10.18176 /$ jiaci.0208

Key words: Flaxseed allergy. Component-resolved diagnosis. Food Allergy. Anaphylaxis.

Palabras clave: Alergia a semillas de lino. Diagnóstico por componentes. Alergia a alimentos. Anafilaxia.

The prevalence of allergy to seeds is highly influenced by the geographical area and eating habits. In Spain, according to data from Alergologica 2015 [1], allergy to tree nuts and seeds accounts for $28.4 \%$ of all cases of food allergy.

Flaxseed is the seed of the plant Linum usitatissimum. It is consumed as a nutritional supplement because it is rich in dietary fiber, polyunsaturated fatty acids, and lignans.

Flaxseed has rarely been reported to be a sensitizer [2], and there are few reports of anaphylaxis caused by flaxseed in the literature [3-6]. However, it is an increasingly common source of allergens as a result of its use in diets for its nutritional benefits and anticancer properties.

Flaxseed contains many potential allergens. The storage protein content ranges from $10 \%$ to $37 \%$, and has been reported to be as high as $20 \%-42 \%$ for conlinin (the low-molecularmass fraction $[2 \mathrm{~S}]$ ) and $58 \%-66 \%$ for linin (the major protein fraction [12S]) [7]. A 56-kDa IgE-binding protein reported in 1 case [5] is thought to correspond to malate dehydrogenase-1. Other authors have recently suggested that the lipid transfer protein (LTP) was the relevant allergen in a case of flaxseed anaphylaxis [8].

We present 2 cases of flaxseed-induced anaphylaxis. Patient 1 was a 46-year-old white woman with a personal history of bronchial asthma and rhinoconjunctivitis who presented with pharyngeal pruritus, lingual and palpebral angioedema, dyspnea, and profuse diarrhea immediately after eating multicereal biscuits (oat, rice, flaxseeds, egg, almonds, and raisins). Patient 2 was a 64-year-old white woman with a personal history of breast cancer, allergy to ceftriaxone, and allergic rhinoconjunctivitis due to pollens and pet dander. She presented palmoplantar itching, generalized urticaria, lip angioedema, and throat tightness immediately after eating a 
salad containing tomato, lettuce, cheese, and flaxseeds. All ingredients but flaxseeds were tolerated afterwards in both cases.

Patient 1 underwent skin prick testing (SPT) with a panel of common aeroallergen extracts. The results were positive only for dog dander. The results of SPT with food extracts were positive to nut, peanut, mustard, tomato, corn, peach, and apple. SPT with commercial cereal extracts (wheat, rice, oat, barley, rye, gluten, and gliadin) were negative. Prick-by-prick testing with flaxseed was positive $(13 \times 9 \mathrm{~mm})$. The results for total IgE and serum specific IgE (UniCAP, Thermo Fisher) were as follows: $282 \mathrm{kU} / \mathrm{L}$ (total); dog dander, $3.26 \mathrm{kU} / \mathrm{L}$; peach, $1.63 \mathrm{kU} / \mathrm{L}$; wheat, $0.54 \mathrm{kU} / \mathrm{L}$; rye, $0.38 \mathrm{kU} / \mathrm{L}$; apple, $1.14 \mathrm{kU} / \mathrm{L}$; tomato, $2.22 \mathrm{kU} / \mathrm{L}$; flaxseed, $1.25 \mathrm{kU} / \mathrm{L}$; Pru p 3, $1.97 \mathrm{kU} / \mathrm{L}$; and $\omega-5$ gliadin $0-\mathrm{kU} / \mathrm{L}$. Specific IgE results were negative for $2 \mathrm{~S}$ albumins (UniCAP, rAra h 2, rBer e 1, r Jug r 1 , rCor a 14, and rAna o 3; and ISAC, rBer e 1, nSes i1, rAra h2, nAra h6, nFag e2, and rJug r1). ISAC microarray (Thermo Fisher) revealed positivity to Can f 5 (35 ISU), Cry j 1 (0.4 ISU), Cup a 1 (1.8 ISU), Ara h 9 (0.3 ISU), Jug r 3 (0.4 ISU), Pru p 3 (0.4 ISU), and Art v 3 (0.5 ISU).

In patient 2, SPT with the common panel of aeroallergen extracts was positive to pollens from Cupressus arizonica, Platanus acerifolia, Phleum pratense, and Plantago lanceolata, as well as to dog and cat dander. SPT with food

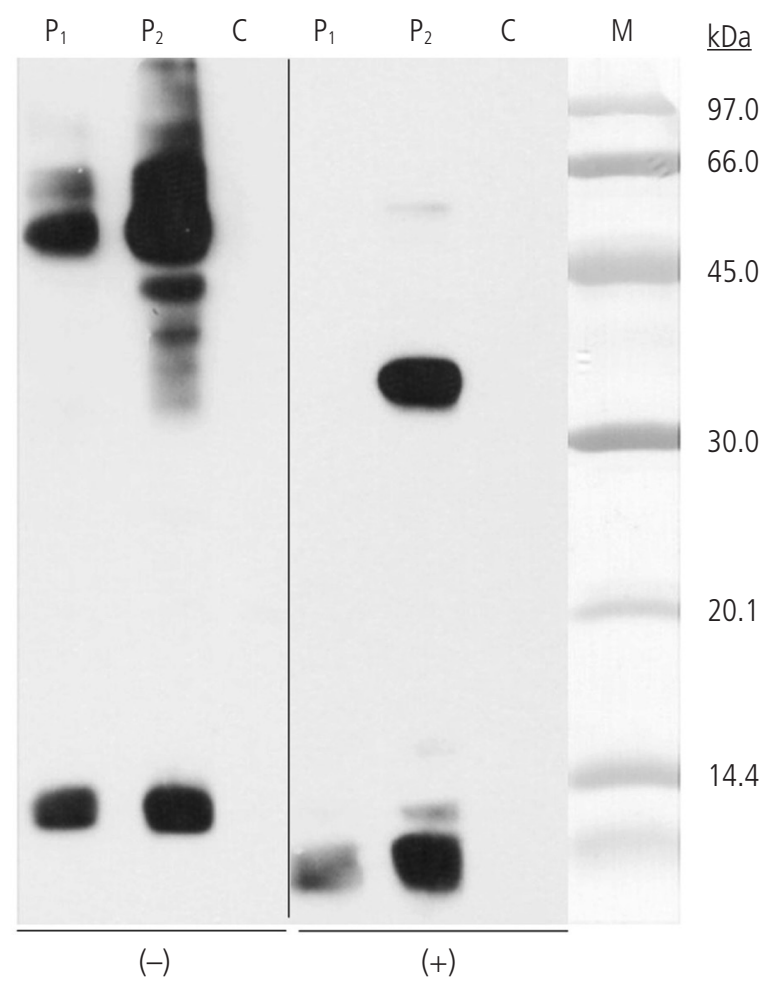

Figure. SDS-PAGE immunoblotting with golden linseed extract. Lane $P_{1}$, serum from patient 1 ; lane $P_{2}$, serum from patient 2 ; lane $C$, control serum (pool of sera from nonatopic subjects); lane $M$, molecular mass standard. (-) samples without 2-mercaptoethanol; (+) samples with 2-mercaptoethanol. extracts was positive to sunflower seed and negative to peanut, almond, hazelnut, walnut, pistachio, Pru p 3, and Pho d 2. Prick-by-prick testing with flaxseed was positive $(10 \times 7 \mathrm{~mm})$. Testing for total IgE and serum specific IgE (UniCAP, Thermo Fisher) revealed the following results: total, $57 \mathrm{kU} / \mathrm{L} ;$ Phleum pratense pollen, $2.17 \mathrm{kU} / \mathrm{L}$; flaxseed, $2.28 \mathrm{kU} / \mathrm{L}$; and sunflower seed, $0.1 \mathrm{kU}_{\mathrm{A}} / \mathrm{L}$. The results of testing were negative for walnut, almond, hazelnut, pistachio, soybean, and sesame seed.

The flaxseed protein extract was prepared by homogenization in phosphate-buffered saline, dialyzation, and lyophilization. SDS-PAGE immunoblotting under nonreducing and reducing conditions was carried out as previously described [9] with linseed extract in sera from both patients. Similar IgE-binding profiles were detected with both sera under nonreducing conditions, namely, bands of $60 \mathrm{kDa}$, $50 \mathrm{kDa}$, and $12 \mathrm{kDa}$ (a $45-\mathrm{kDa}$ band was also observed in the serum of patient 2). Under reducing conditions, both sera revealed an IgE-binding band of $8 \mathrm{kDa}$, and a $34-\mathrm{kDa}$ band was also detected in serum from patient 2 (Figure).

Bands of $50 \mathrm{kDa}$ and $12 \mathrm{kDa}$ (without 2-mercaptoethanol) and $8 \mathrm{kDa}$ and $34 \mathrm{kDa}$ (with 2-mercaptoethanol) were extracted from the gel and digested with trypsin, and the proteins were analyzed using mass spectrometry LC-MSMS (HR, ORBITRAP, short gradient), as previously described [10]. Peptides from the protein conlinin (a $2 \mathrm{~S}$ storage protein of flaxseed) were identified in all the bands.

We present 2 cases of IgE-mediated anaphylaxis caused by flaxseed that were confirmed by positive prick-by-prick test results, serum specific IgE determination, and immunoblot assay. In 1 patient, mass spectrometry revealed the seed storage protein conlinin to be the relevant allergen. Conlinin may also have been involved in the second patient, since similar allergenic bands were seen in the immunoblot assay.

Antolin-Amerigo et al [8] identified a 9-kDa allergenic protein by Western blot in a case of anaphylaxis to flaxseed and concluded that the protein could be the flaxseed LTP, assuming that the LTP was the culprit allergen, since serum sIgE to LTP of pollens and peach were positive (as shown in Patient 1). However, this patient tolerated fruits and nuts, and the protein was not sequenced.

Tolerance of other foods and negative results with serum specific IgE against other purified $2 \mathrm{~S}$ albumins indicate probable low cross-reactivity between flaxseed conlinin and $2 \mathrm{~S}$ albumins of other plant species. Although patient 2 had positive skin test results with sunflower seed, we could not determine their clinical relevance, since the patient did not eat sunflower seeds.

In conclusion, our study of 2 cases of anaphylaxis caused by flaxseed ingestion revealed the culprit allergen to be the seed storage protein conlinin. To date, this is the first flaxseed allergen identified.

\section{Funding}

The authors declare that no funding was received for the present study.

\section{Conflicts of Interest}

The authors declare that they have no conflicts of interest. 


\section{References}

1. Alergológica 2015: Factores epidemiológicos, clínicos y socioeconómicos de las enfermedades alérgicas en España en 2015. Draft Grupo de Comunicación HealthCare. 2017.

2. Fremont $S$, Moneret-Vautrin DA, Franck $P$, Morisset $M$, Croizier $A$, Codreanu $F$, et al. Prospective study of sensitization and food allergy to flaxseed in 1317 subjects. Eur Ann Allergy Clin Immunol. 2010;42(3):103-11.

3. Alonso L, Marcos ML, Blanco JG, Navarro JA, Juste S, del Mar Garces $M$, et al. Anaphylaxis caused by linseed ( $f$ l axseed) intake. J Allergy Clin Immunol. 1996;98(2):469-70.

4. Lezaun A, Fraj J, Colas C, Duce F, Dominguez MA, Cuevas M, et al. Anaphylaxis from linseed. Allergy. 1998;53(1):105-6.

5. Leon F, Rodriguez M, Cuevas M. The major allergen of linseed. Allergy. 2002;57(10):968.

6. Alvarez-Perea A, Alzate -Pérez D, Doleo Maldonado A, Baeza ML. Anaphylaxis caused by flaxseed. J Investig Allergol Clin Immunol. 2013;23:446-7.

7. Truksa M, MacKenzie S, Qiu X. Molecular analysis of Flax $2 S$ storage protein conlinin and seed specific activity of its promoter. Plant Physiology and Biochemistry 41 (2003) 141 7.

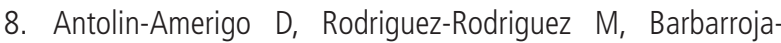
Escudero J, Sánchez-González MJ, Haroun-Diaz E, CuestaHerranz J, et al. Linseed Allergy due to LTP: another food for LTP Syndrome. J Investig Allergol Clin Immunol. 2016;26(6):376377.

9. Towbin H, Staehelin T, Gordon J. Electrophoretic transfer of proteins from polyacrylamide gels to nitrocellulose sheets: procedure and some applications. Proc Natl Acad Sci USA. 1979;76 (9):4350-4.

10. Pastor C, Cuesta-Herranz J, Cases B, Pérez- Gordo M, Figueredo $E$, de las Heras $M$, et al. Identification of major allergens in watermelon. Int Arch Allergy Immunol. 2009;149:291-8.

Manuscript received July 20, 2017; accepted for publication October 17, 2017.

Maria Basagaña Torrentó Allergy Unit Hospital Universitari Germans Trias i Pujol Crta/ Del Canyet, s/n 08916 Badalona, Spain E-mail: maria.basagana.torrento@gmail.com 